\title{
Genetic characterization of Genista sericea Wulfen (Cytiseae - Fabaceae) as revealed by nuclear DNA content and ITS nrDNA region analysis
}

\author{
LILIANA VižInTIN $^{1 *}$, Vera KOSOVEL ${ }^{2}$, LAURA FeOLI ChIAPElla $^{2}$, \\ BORUT BOHANEC ${ }^{1}$ \\ ${ }^{1}$ University of Ljubljana, Biotechnical Faculty, Jamnikarjeva 101, 1111 Ljubljana, \\ Slovenia \\ ${ }^{2}$ University of Trieste, Department of Life Sciences, via Giorgieri 10, 34127 Trieste, Italy
}

\begin{abstract}
Summary - Genista sericea Wulfen, a northern Illyrian amphi-Adriatic species, presents a certain morphological variability. To clarify whether the genetic variations support the morphological differences among accessions of different geographic origin, analysis of nuclear DNA content and polymorphism of the internal transcribed spacer (ITS) dataset was studied. The variation in nuclear DNA content of $G$. sericea var. sericea and var. rigida is minimal (2.09 and $2.08 \mathrm{pg} /$ nucleus respectively) and is correlated with equal chromosome numbers in both varieties. Intraspecific variability of the ITS region was studied on 13 accessions of $G$. sericea, 6 belonging to var. sericea and 7 to var. rigida. These accessions were analyzed in comparison to closely related species already studied. ITS sequences of $G$. sericea revealed large polymorphism and formed two main clusters. One cluster (6 accessions) comprehends var. sericea of northern Italy, Slovenia and northern Croatia; the other cluster ( 7 accessions) includes five accessions of var. rigida from southern Croatia and Montenegro and two from the Pollino massif (southern Italy). The later two accessions considerably differed from other accessions of var. rigida. This genetic analysis supports the previous assumptions, which subdivided G. sericea into at least two taxa. On the basis of the results presented, it is here suggested that the subdivision of $G$. sericea into var. sericea and var. rigida should be maintained.
\end{abstract}

Key words: Fabaceae, Genista sericea, genome size, ITS, phylogenic analysis.

Abbreviations: DAPI - 4, 6-diamidino-2-phenylindole, ITS - internal transcribed spacer, PI - propidium iodide.

\section{Introduction}

Genista sericea Wulfen, a northern Illyrian amphi-Adriatic species, has a range from northeastern Italy to Albania, with a disjunct distribution on the Pollino massif, Calabria, Italy (PAMPANINI 1912, GIBBS 1966, CoNTI et al. 2005).

* Corresponding author, e-mail address: lili.vizintin@gmail.com

Copyright $^{\circledR} 2012$ by Acta Botanica Croatica, the Faculty of Science, University of Zagreb. All rights reserved. 
Within the species, PAMPANINI (1912) distinguished var. sericea and var. rigida. In the first taxon the non-flowering branches are elongated and flexuous; the leaves are lanceolate and acute with a glabrous upper surface. In the second taxon the branches are shorter, more strongly ribbed and rigid; the leaves are ovate, broader and thicker, especially the young, with a sparsely pubescent upper surface. Whereas var. sericea is distributed in the northern part of the range (northeastern Italy and northern part of the Illyrian region), var. rigida is spread in the southern part of the Illyrian region (Dalmatia, Bosnia-Hercegovina, Montenegro, Albania) and on the Pollino massif (Italy). In recent literature, var. rigida is not considered (GiBbs 1966, PignATti 1982, ConTi et al. 2005).

In northern Italy, var. sericea occurs along the southern slopes of the Alps; it is frequent in the east (Friuli Venezia Giulia, particularly in the karst area near Trieste), while it becomes rarer towards the west, in southern Veneto and southern Trentino. In Slovenia, var. sericea is present only in the south west. In Croatia it occurs in the northwestern area, especially in Kvarner (PAmpanini 1912, Pignatti 1982, Feoli Chiapella and Rizzi Longo 1987, CONTI et al. 2005).

Genista sericea belongs to sect. Spartioides Spach. According to its morphological and phytochemical characters, it is known as a heterogeneous section that does not form a monophyletic group. Because of the molecular data, the species of this section are included in separate groups intermingled with species of other sections and several intersectional hybrids are also present (PARDO et al. 2004). This heterogeneity was confirmed also by karyological and palynological data (CANTÓ et al. 1997; CUSMA VELARI et al. 2003, 2009; Rizzi Longo and FEOLI CHIAPELla 2009). The species of this section occur mostly in the Mediterranean region, with two main distribution centers: a Western (southern Spain and northwestern Africa) and an Eastern one (Balkan Peninsula and Anatolia) (GIBBS 1966, CANTó et al. 1997).

Rizzi LONGO and FEOLI CHIAPELLA (1993) carried out a pollen morphology analysis of G. sericea by light microscope and SEM, where var. sericea and var. rigida differ in some quantitative (grain dimensions) and qualitative (shape of amb and furrows) characters. CUSMA Velari et al. (1996) have determined the chromosome number of G. sericea var. serice and var. rigida: $2 \mathrm{n}=4 \mathrm{x}=48$.

The nuclear ribosomal DNA (nrDNA) internal transcribed spacer region (ITS) has proven a useful source of characters for phylogenetic studies in many Angiosperm families including Leguminosae (ÁlvAREZ and WENDEL 2003). Many genera of Cytiseae (KAESS and WINK 1997b), Lupinus (BADR et al. 1994, KAESS and WINK 1997a), Genista (DE CASTRO et al. 2002), Genista and related genera as Teline, Echinospartum, Retama, Stauracanthus (PARDO et al. 2004), Cytisus and allied genera such as Argyrocytisus, Calicotome, Cytisophyllum (CuBAs et al. 2002), Adenocarpus, Genista and Teline (PERCY and CronK 2002) and Ulex (AiNOUCHE et al. 2003), have already been analyzed.

Although molecular data are considered the most convincing data set, which can be used to identify phylogenetic relationships, a combination of different data sets, including genome size data, provides useful information on genetic similarity and taxonomic position (VižInTIN et al. 2006). Most reports (LEITCH and BENNETT 2002) confirmed that genome size is usually a value with limited variations within a single species and could be considered characteristic of the species. Flow cytometry could be used for estimations of genome size in absolute units using intercalating fluorochrome PI stained nuclei (NOIROT et 
al. 2002) or for an intraspecific comparison in relative units using DAPI, an AT base specific dye (BUITENDIJK et al. 1997). Genome size data concerning the taxa Genista, Cytisus, Lembotropis and Argyrocytisus are rather scarce.

The aim of our study is to assess the intraspecific variability of G. sericea, highlighting the possible differences between var. sericea and var. rigida at a molecular level through the analyses of nrDNA regions ITS1 and ITS2. Furthermore, as genome size has not yet been determined for $G$. sericea, our aim is to provide data on genome size in both varieties.

\section{Materials and methods}

\section{Plant material}

Genome size determination was performed with fresh plant material. Accessions used for the flow cytometry analyses were: G. sericea var. sericea, collected at Opicina and Monrupino (Trieste - Italy) and G. sericea var. rigida, collected on the Pollino massif (Calabria, Italy) (Tab. 1).

Tab. 1. Propidium iodide and DAPI flow cytometric genome size determination in the examined populations of Genista sericea.

\begin{tabular}{|c|c|c|c|c|}
\hline $\begin{array}{l}\text { Staining } \\
\text { method }\end{array}$ & Taxon & Accession & $\begin{array}{l}\text { No. } \\
\text { plant }\end{array}$ & $\begin{array}{c}\text { Average 2C } \\
(\mathrm{pg}) \pm \mathrm{SD}\end{array}$ \\
\hline \multicolumn{5}{|c|}{ PI staining } \\
\hline & G. sericea var. sericea & Opicina (Trieste, Italy) 90579 (TSB) & 5 & $2.09 \pm 0.03$ \\
\hline & G. sericea var. rigida & M. Pollino (Cosenza, Italy) 90582 (TSB) & 5 & $2.08 \pm 0.03$ \\
\hline \multicolumn{5}{|c|}{ DAPI staining } \\
\hline & \multirow[t]{2}{*}{ G. sericea var. sericea } & Opicina (Trieste, Italy) 90579 (TSB) & 4 & $1.96 \pm 0.02$ \\
\hline & & Monrupino (Trieste, Italy) 90580 (TSB) & 4 & $1.95 \pm 0.02$ \\
\hline & G. sericea var. rigida & Pollino (Cosenza, Italy) 90582 (TSB) & 4 & $1.95 \pm 0.03$ \\
\hline
\end{tabular}

The extraction of DNA for molecular analyses was performed from herbarium plant material. Different accessions of $G$. sericea were examined: six belonging to var. sericea and seven to var. rigida. The studied accessions, with their geographical origin and NCBI Genbank number are listed in table 2 and figure 1. Voucher specimens are deposited in the Herbarium of the Department of Life Sciences, University of Trieste, Italy (TSB). The classification of PAMPANINI (1912) was followed.

\section{Determination of nuclear DNA content by flow cytometry}

The relative and absolute value of DNA content was assessed by flow cytometry using Trifolium pratense L. as standard. The genome size $(0.85 \mathrm{pg})$ was previously estimated for this species using Trifolium repens L. cv. Milo as standard (VižINTIN et al. 2006).

For the determination of absolute DNA content, tissues from green and young stems of the analyzed samples, together with leaf tissues of the standard species, were chopped with a razor blade in plastic Petri dishes in cold LB01 buffer, according to a technique adapted 
Vižintin L., Kosovel V., Feoli Chiapella L., Bohanec B.

Tab. 2. Accession data of the populations of Genista sericea sampled for phylogenetic analyses in the ITS region of nrDNA: origin, collector and NCBI GeneBank accession numbers.

\begin{tabular}{|c|c|c|c|c|c|}
\hline \multirow[t]{2}{*}{ Taxon } & \multirow[t]{2}{*}{ Sample } & \multirow[t]{2}{*}{ Origin } & \multirow[t]{2}{*}{ Collector } & \multicolumn{2}{|c|}{ GeneBank accession No } \\
\hline & & & & ITS1 & ITS 2 \\
\hline \multirow[t]{6}{*}{$\begin{array}{l}\text { G. sericea } \\
\text { var. sericea }\end{array}$} & GS17 & $\begin{array}{l}\text { Vivaro, Pordenone, Italy, } \\
15 / 10 / 2000,84731 \text { (TSB) }\end{array}$ & L. Feoli Chiapella & EU525894 & EU525906 \\
\hline & GS19 & $\begin{array}{l}\text { Pinedo di Claut, Pordenone, } \\
\text { Italy, 23/5/1999, } 84728 \text { (TSB) }\end{array}$ & C. Coran & EU525896 & EU525908 \\
\hline & GS18 & $\begin{array}{l}\text { Mt. Čaven, Nova Gorica, } \\
\text { Slovenia, 10/5/1999, } 84730 \text { (TSB) }\end{array}$ & L. Feoli Chiapella & EU525895 & EU525907 \\
\hline & GS20 & $\begin{array}{l}\text { Mt. Nanos, Nova Gorica, } \\
\text { Slovenia, 29/5/1999, } 84726 \text { (TSB) }\end{array}$ & L. Feoli Chiapella & EU525893 & EU525909 \\
\hline & GS2 & $\begin{array}{l}\text { Baščanska Draga - Punat, Krk, } \\
\text { Croatia, 24/4/1966, } 84138 \text { (TSB) }\end{array}$ & M. Tarabocchia & EU525897 & EU525910 \\
\hline & GS15 & $\begin{array}{l}\text { Capo Pax Tecum - Plomin, } \\
\text { Istria, Croatia, } 70 \text { m, 26/4/1964, } \\
84139 \text { (TSB) }\end{array}$ & T. Mozenich & EU525898 & EU525911 \\
\hline \multirow[t]{7}{*}{$\begin{array}{l}\text { G. sericea } \\
\text { var. rigida }\end{array}$} & GS12 & $\begin{array}{l}\text { Biokovo, Kozica, Croatia, } \\
600 \text { m, 30/4/2001, } 84457 \text { (TSB) }\end{array}$ & L. Feoli Chiapella & EU525904 & EU525917 \\
\hline & GS9 & $\begin{array}{l}\text { Kuči, Donji Medun, Podgorica, } \\
\text { Montenegro, 3/6/1998, } 84143 \\
\text { (TSB) }\end{array}$ & V. Karaman & EU525900 & EU525913 \\
\hline & GS10 & $\begin{array}{l}\text { Kakarička gora, Masline, } \\
\text { Podgorica, Montenegro, } 173 \text { m, } \\
\text { 3/6/1998, } 84456 \text { (TSB) }\end{array}$ & V. Karaman & EU525901 & EU525914 \\
\hline & GS11 & $\begin{array}{l}\text { Piperi, Podgorica, Montenegro, } \\
300 \mathrm{~m}, 17 / 5 / 1998,90581 \text { (TSB) }\end{array}$ & V. Karaman & EU525902 & EU525915 \\
\hline & GS13 & $\begin{array}{l}\text { Cijevna reka, Montenegro, } \\
27 / 5 / 2000,84451 \text { (TSB) }\end{array}$ & S. Hadžiablahovič & EU525903 & EU525916 \\
\hline & GS4 & $\begin{array}{l}\text { Timpone Dolcetti, Pollino, } \\
\text { Cosenza, Italy, 9/6/1997, } \\
84141 \text { (TSB) }\end{array}$ & D. Puntillo & EU525899 & EU525912 \\
\hline & GS16 & $\begin{array}{l}\text { Morano Calabro, Pollino, Cosenza, } \\
\text { Italy, 3/6/1997, } 84140 \text { (TSB) }\end{array}$ & A. Vaccaro & EU525905 & EU525918 \\
\hline
\end{tabular}

from DolEžEL et al. (1989). The suspension was passed through a $30 \mu \mathrm{m}$ nylon-mesh filter and nuclei were stained with $50 \mu \mathrm{g} \mathrm{mL}^{-1}$ of PI and $50 \mu \mathrm{g} \mathrm{mL}^{-1}$ ribonuclease.

For the determination of relative DNA content, the staining was performed with DAPI and the procedure was modified according to Отто (1988). Nuclei of our sample and of the standard species were released in $0.1 \mathrm{M}$ citric acid containing $0.5 \%$ Tween 20 . The suspension was filtered through a $30 \mu \mathrm{m}$ nylon-mesh filter. A $4 \mathrm{x}$ volume of staining buffer containing $4 \mu \mathrm{g} \mathrm{mL}^{-1}$ DAPI and $0.4 \mathrm{M}$ disodium hydrogen phosphate was added.

Measurements were done on a Partec PAS flow cytometer using a linear scale. For PI staining, samples were analyzed using an argon laser tuned to $488 \mathrm{~nm}$, with emissions measured through an RG 590 long-pass optical filter. For DAPI staining, the UV spectrum ex- 


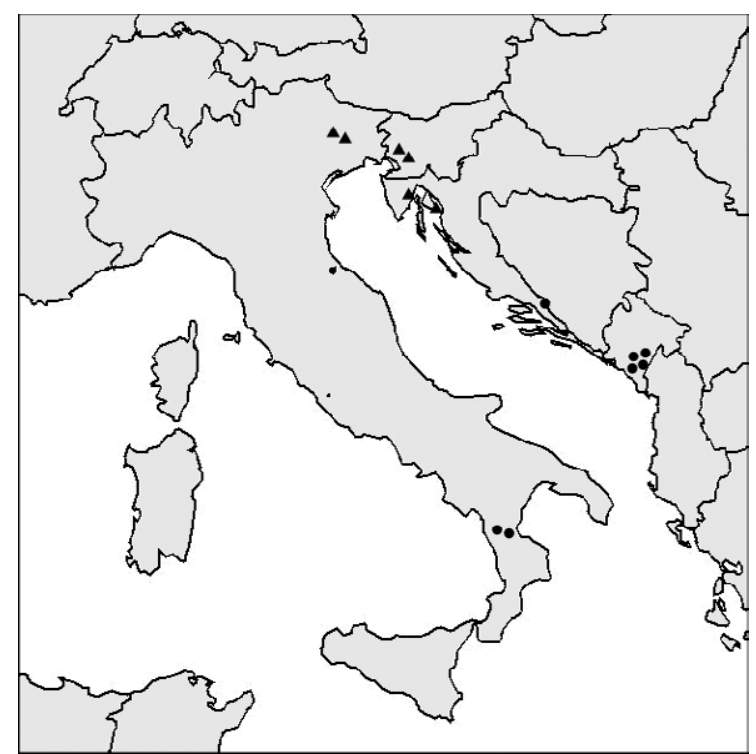

Fig. 1. Geographycal origin of the examined accessions of Genista sericea. $\Delta$ G. sericea var. sericea, $\bullet$ G. sericea var. rigida

cited with a HBO lamp was used and emissions were measured through a GG 435 long-pass filter. Seven thousand nuclei per sample were measured and at least four repetitions of different nuclear isolations were performed for each species. Flomax® software (Partec, Münster) was used to calculate the positions of G0/G1 peaks of standard and investigated accessions. The analysis was completed in a short period to minimize the seasonal variation effect.

\section{Analysis of the ITS region of rDNA}

Genomic DNA was extracted from herbarium plant material applying CTAB mini DNA extraction protocol according to COMPTON et al. (1998) with slight modifications. The ribosomal ITS 1 and 5.8 S -ITS 2 regions were separately amplified using, respectively, ITS1-ITS2 and ITS3-ITS4 primers designated by WHITE et al. (1990). Amplification was carried out by means of a polymerase chain reaction in $50 \mu 1$ reaction mixture containing 1 x Taq polymerase buffer (Promega, Madison, WI, USA), $200 \mu \mathrm{M}$ of each dNTP, $0.5 \mu \mathrm{M}$ of each primer, $100 \mathrm{ng}$ DNA and 2.5 units of Taq polymerase (Promega). Optimized amplification was performed in a PTC-150-16E-25 M.J. Research Inc. thermal minicycler programmed as follows: (A) an initial 3 min denaturation at $95^{\circ} \mathrm{C}$; (B) 35 cycles of denaturation at $93{ }^{\circ} \mathrm{C}$ for $35 \mathrm{sec}$, annealing at $49^{\circ} \mathrm{C}$ for $35 \mathrm{sec}$ and polymerisation at $72{ }^{\circ} \mathrm{C}$ for 2 $\min$; (C) final extension at $72{ }^{\circ} \mathrm{C}$ for $7 \mathrm{~min}$. The amplified DNA products were sequenced from both sides by Macrogen Inc. (Seoul, Korea) using the same primers on an ABI 3730 XLDNA analyser (Applied Biosystems, Renton, USA). Sequence results from each amplified fragment were visualized and edited to obtain an optimized consensus sequence using CodonCode Aligner ver. 1.4.6 (CodonCode Corporation, USA). Nucleotide sequences were deposited in the GenBank database with the accession numbers reported in table 2. 


\section{Phylogenetic analysis of ITS sequences}

The initial data matrix was aligned using ClustalX (ver. 1.83). A phylogenetic tree was constructed using the Maximum Likelihood method based on the Tamura 3-parameter model (TAMURA 1992) on Mega 5.0 software (TAMURA et al. 2011). Bootstrapping was performed at one thousand replicates to assess the confidence values of the clusters formed. Bootstrap data are shown next to the branches. A discrete Gamma distribution was used to model evolutionary rate differences among sites. The tree is drawn to scale, with branch lengths measured in the number of substitutions per site. There were a total of 508 positions in the final dataset.

An accession of Cytisus was used as an outgroup. Several sequences of closely related Genista species from the section Spartioides, already available in the GenBank, have also been included in the ITS analyses to obtain a more comprehensive picture. Accession numbers and sources of these sequences are indicated in table 3.

Tab. 3. Accession data and sequences of ITS region obtained from NCBI GenBank.

\begin{tabular}{lcc}
\hline Taxon & References & $\begin{array}{c}\text { GeneBank } \\
\text { accession No. }\end{array}$ \\
\hline Genista cinerea subsp. speciosa Rivas Mart. et al. & PARDO et al. 2004 & AY263637 \\
Genista cinerea subsp. ausetana O. Bolož s et Vigo & PARDO et al. 2004 & AY263638 \\
Genista cinerea (Vill.) DC. subsp. cinerea & PARDO et al. 2004 & AY263636 \\
Genista majorica Canto et M.J. Sanchez & PARDO et al. 2004 & AY263652 \\
Genista ramosissima (Desf.) Poir. & PARDO et al. 2004 & AY263662 \\
Genista valentina (Sprengel) Steud. & PARDO et al. 2004 & AY263676 \\
Cytisus scoparius (L.) Link subsp. scoparius & CUBAS et al. 2002 & AF351120 \\
\hline
\end{tabular}

\section{Results}

\section{Analysis of nuclear DNA content}

Genome size values and base composition were determined for five plants of both varieties of G. sericea (var. sericea and var. rigida) using PI staining and for four plants of each accession of the two varieties using DAPI (Tab. 1). Determination using PI serves as an estimation of absolute nuclear DNA content, while determination using DAPI serves as a comparison for further intraspecific analysis. The absolute value of nuclear DNA content for var. sericea is $2.09 \mathrm{pg}$ DNA per nucleus. The value obtained for var. rigida is $2.08 \mathrm{pg}$ DNA per nucleus.

Because lower CV values cause higher resolution, DAPI staining was additionally used to test more accurately the intraspecific genome size variation: G. sericea var. sericea presents a relative nuclear DNA content of $1.95-1.96 \mathrm{pg}$ per nucleus and var. rigida $1.95 \mathrm{pg}$ per nucleus. Results obtained with DAPI staining confirmed that the variability of genome size is rather small between the two varieties of $G$. sericea and is not useful for the characterization of the varieties.

It should be noted that the values obtained by PI staining have given higher estimations of DNA content, suggesting unequal AT/GC content. 


\section{Polymorphism of the ITS region of rDNA}

The internal transcribed spacer (ITS1 and ITS2) region of ribosomal DNA was sequenced from 13 accessions of $G$. sericea (Tab. 2). Each examined sequence produced a slightly different sequence profile; their alignment resulted in a matrix of 508 characters. A high variability of ITS nucleotide sequences was discovered exhibiting 22 variable sites.

The nucleotide sequences of amplified ITS regions were used to construct a phylogenetic tree (Fig. 2) to assess the relationships among the analyzed accessions. The ITS tree reveals two major clades, bootstrap support was 74 . One clade is formed by all the accessions of var. sericea, from Friuli - Venezia Giulia (Italy), Slovenia and northern coast of Croatia. The other clade includes the accessions of var. rigida from southern Croatia coast and Montenegro. The two accessions of var. rigida from Pollino massif (southern Italy) stand at the base, but the bootstrap support is low.

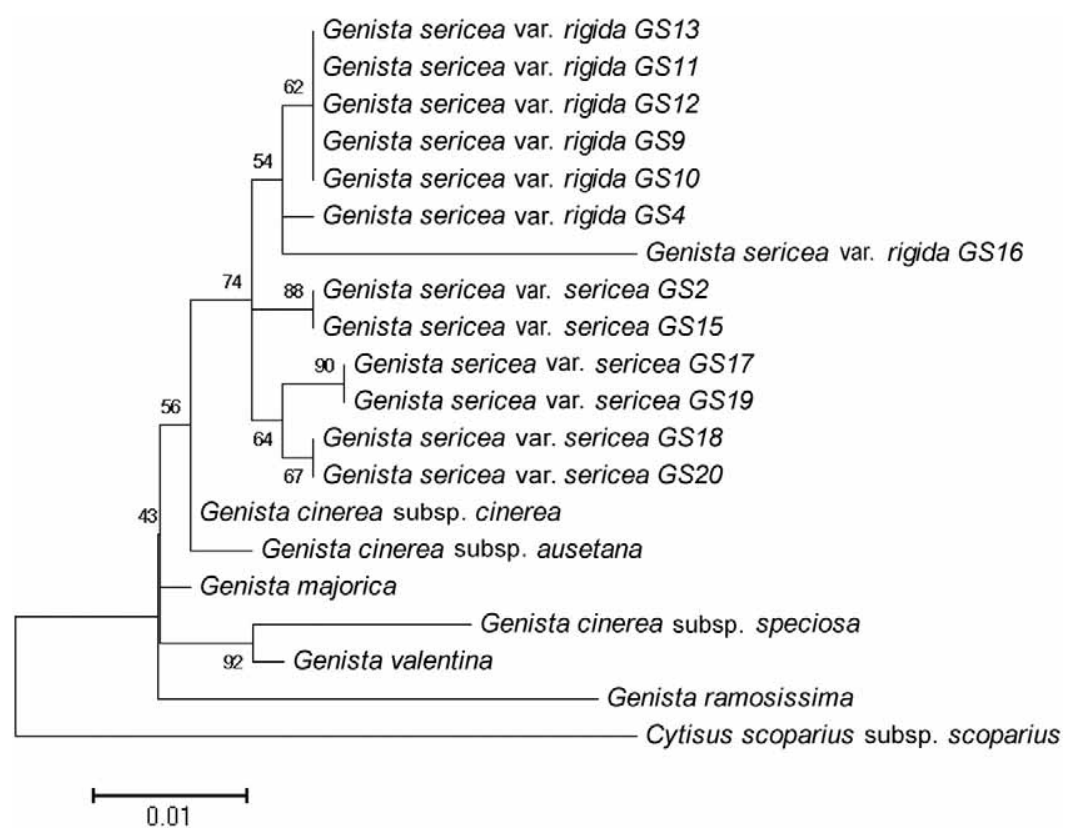

Fig. 2. Phylogram of 13 populations of Genista sericea and of 6 related species of the genus Genista. Cytisus scoparius subsp. scoparius was added as an outgroup.

\section{Discussion}

The accessions of $G$. sericea var. sericea and var. rigida present a very similar nuclear DNA content (2.09 and $2.08 \mathrm{pg}$ per nucleus); also the relative nuclear DNA content is similar in the two varieties (1.95 - 1.96 and 1.95 pg per nucleus). The nuclear DNA content in a wild population of a species of Genista sericea is presented for the first time in this study, as the only data in literature regarding this genus are those of BELLENOT-KAPUSTA et al. (2006), who studied some ornamental brooms (as G. tinctoria, G. lydia, G. pilosa, G. hispanica and G. aetnensis) the 2C DNA content of which varies from 1.60 to 3.56, and of SUDA et al. 
(2005) who determined the nuclear DNA content value for G. benehoavensis as $4.60 \mathrm{pg}$. In particular the 2C DNA content of G. pilosa, the only species previously examined of sect. Spartioides, is $1.99 \mathrm{pg}$, while in G. tinctoria and G. lydia of the affine sect. Genista is 1.73 and $1.74 \mathrm{pg}$. Data concerning other genera of Cytiseae, wild and cultivated plants of Cytisus, Lembotropis, Argyrocytisus and Laburnum, were published by BELLENOT-KAPUSTA et al. (2006) and OLSZEWSKA and OSIECKA $(1983,1984)$ : the analyzed 2C DNA content varies from 1.10 to 4.40. MissET and GouRRET (1996) determined the genome size of Ulex (7.7 pg/2C). OBERMAYER et al. (1999) and NAGANOWSKA et al. (2006) have studied many species of Lupinus (2C content from 1.15 to 2.68), a genus distant from the others of Cytiseae.

Because of the obtained genome size data, morphological differences between the two varieties of $G$. sericea are not correlated with significant differences in genome size and this led us to suppose that no major insertions or deletions of DNA segments occurred in any of varieties. This result is correlated with chromosome studies which showed the same number in both varieties ( $2 n=4 x=48$; CUSMA VelARI et al. 1996).

Both varieties of $G$. sericea formed clearly separated clades (74 bootstrap supports) which did not intermingle with other related Genista species. Although analysis of ITS region is mainly used for interspecific phylogeny, this study indicates that genetic variation of ITS region in $G$. sericea was in this case sufficient to resolve both subspecies. In $G$. sericea the data presented reflect the separation of two distinct groups of accessions, the first comprehending all the accessions of var. sericea from northern Italy, Slovenia and northern Croatia, the second including all the accessions of var. rigida collected in southern Croatia, Montenegro and in southern Italy.

Molecular data are in accordance with morphological characteristics and pollen differences (Rizzi Longo and FEOLi ChiAPELla 1993), as well as seed dimensions (CUSMA VelARI and FEOLI CHIAPELLA, personal observations). Our analysis supports the subdivision of G. sericea into two taxa (var. sericea and var. rigida). On the basis of molecular data, the accessions of the Pollino massif (Calabria, Italy) attributed by PAMPANINI (1912) to var. rigida are related to those of southern Croatia and Montenegro, but do show diversification within var. rigida that could be further studied.

\section{Acknowledgements}

This research was supported by a grant from the Ministry of Foreign Affairs of the Italian Republic and in part by a project (P4-0077) of the Ministry of Higher Education, Science and Technology of the Republic of Slovenia.

We would like to thank Prof. L. Bernardo (Cosenza), Dr. D. Puntillo (Cosenza), Prof. A. Vaccaro (Acri), Dr. D. and V. Vincek (Kolašin) for supplying us with some plants and Dr. Lucia Feoli, for correcting the English version.

\section{References}

Ainouche, A., Bayer, R. J., Cubas, P., Misset, M. T., 2003: Phylogenetic relationships within tribe Genisteae (Papilionoideae) with special reference to genus Ulex. In: Klitgaard, B. B., Bruneau, A. (eds.), Advances in legume systematics, 10. Higher level systematics, 239-252. Royal Botanic Gardens, Kew. 
Álvarez, I., Wende, J. F., 2003: Ribosomal ITS sequences and plant phylogenetic inference, Molecular Phylogenetics and Evolution 29, 417-434.

BAdR, A., MARTin, W., JENSEN, U., 1994: Chloroplast DNA restriction site polyphormism in Genisteae (Leguminosae) suggest a common origin for European and American Lupinus. Plant Systematics and Evolution 193, 95-106.

Bellenot-Kapusta, V., Pesteil, C., Cadic, A., 2006: Diversity study and breeding of brooms (tribe of Genisteae). Acta Horticulturae (ISHS) 714, 29-36. http://www. actahort.org/books/714/714. Access June 11, 2012.

BuitendiJK, J. H., Boon, E. J., RAmAnnA, M. S., 1997: Nuclear DNA content in twelve species of Alstroemeria L. and some of their hybrids. Annals of Botany 79, 343-353.

Cantó, P., Rivas-Martínez, S., Greinwald, R., Van Rensen, I., 1997: Revisión de Genista L. sect. Spartioides Spach en la península Ibérica y Baleares. Lazaroa 18, 9-44.

Compton, J. A., Culham, A., Gibbings, J. G., Jury, S. L., 1998: Phylogeny of Actaea including Cimicifuga (Ranunculaceae) inferred from nrDNA ITS sequence variation. Biochemical Systematics and Ecology 26, 185-197.

Conti, F., Abbate, G., Alessandrini, A., Blasi, C., 2005: An annotated checklist of the Italian vascular flora. Palombi Editori, Roma.

CubAs, P., PARdo, C., TAhIRI, H., 2002: Molecular approach to the phylogeny and systematics of Cytisus (Leguminosae) and related genera based on nucleotide sequences of nrDNA (ITS region) and cpDNA (trnL-trnF intergenic spacer). Plant Systematics and Evolution 233, 223-242.

Cusma Velari, T., Feoli Chiapella, L., Kosovel, V., 1996: Osservazioni cariosistematiche sul gruppo di Genista sericea. Giornale Botanico Italiano 130, 369.

Cusma Velari, T., Feoli Chiapella, L., Kosovel, V., 2003: Karyological notes on Genista sect. Spartioides Spach with emphasis on western species and G. pilosa L. (Genisteae-Fabaceae). Studia Geobotanica 22, 55-64.

Cusma Velari, T., Feoli Chiapella, L., Kosovel, V., 2009: Karyomorphology and systematics of the eastern taxa of Genista sect. Spartioides and G. pulchella (Genisteae-Fabaceae). Caryologia 62, 102-113.

De Castro, O., Cozzolino, S., Jury, S. L., Caputo, P., 2002: Molecular relationships in Genista L. Sect. Spartocarpus Spach (Fabaceae). Plant Systematics and Evolution 231, 91-108.

Doležel, J., Binarova, P., Lucretti, S., 1989: Analysis of nuclear DNA content in plant cells by flow cytometry. Biologia Plantarum 31, 113-120.

Feoli Chiapella, L., Rizzi Longo, L., 1987: Distribuzione ed ecologia del genere Genista L. nel Friuli-Venezia Giulia. Biogeographia 13, 119-154.

GiBBS, P. E., 1966: A revision of the genus Genista L. Notes from the Royal Botanic Garden, Edinburgh 27, 11-99.

KAESS, E., WinK, M., 1997a: Molecular phylogeny and phylogeography of Lupinus (Leguminosae) inferred from nucleotide sequences of the rbcL gene and ITS 1+2 regions of rDNA. Plant Systematics and Evolution 208, 139-167. 
KAESS, E., WinK, M., 1997b: Phylogenetic relationships in the Papilionoideae (Family Leguminosae) based on nucleotide sequences of cpDNA (rbcL) and ncDNA (ITS 1 and 2). Molecular Phylogenetics and Evolution 8, 65-88.

LEITCH, I. J., BENNETT, M. D., 2002: New insights into patterns of nuclear genome size evolution in plants. Current Genomics 3, 551-562.

MisSET, M. T, GOURRET, J. P., 1996: Flow cytometric analysis of the different ploidy levels observed in the genus Ulex L. Faboideae-Genisteae in Brittany (France). Botanica Acta 109, 72-79.

NAGANOWsKa, B., Wolko, B., SLiwinska, E., KACZMAREK, Z., SCHIFINO-WiTTMANN, M. T., 2006: 2C DNA variation and relationships among New world species of the genus Lupinus (Fabaceae). Plant Systematics and Evolution 256, 147-157.

Noirot, M., BARre, P., LOUARn, J., DuPERray, C., HAMON, S., 2002: Consequences of Stoichiometric Error on Nuclear DNA Content Evaluation in Coffea liberica var. dewevrei using DAPI and Propidium Iodide. Annals of Botany 89, 385-389.

OBERMAYER, R., SwiECICKI, W. K., GReILHUbER, J., 1999: Flow cytometric determination of genome size in some Old World Lupinus species (Fabaceae). Plant Biology 1, 403-407.

OLSZEWSKA, M. J., OSIECKA, R., 1983: The relationship between 2C DNA content, life cycle type, systematic position and the dynamics of DNA endoreduplication in parenchyma nuclei during growth and differentiation of roots in some dicotyledonous herbaceous species. Biochemie und Physiologie der Pflanzen 178, 581-599.

OLSZEWSKA, M. J., OSIECKA, R., 1984: The relationship between 2C DNA content, systematic position and the level of nuclear DNA endoreduplication during differentiation of root parenchyma nuclei in some dicotyledonous shrubs and tree. Biochemie und Physiologie der Pflanzen 179, 641-657.

OTTO, F., 1988: High resolution DNA-flow cytometry using DAPI. Protocol, 1. Partec, Arlesheim, Münster.

PAMPANINI, R., 1912: La Genista sericea Wulf. e la sua distribuzione in Italia. Nuovo Giornale Botanico Italiano 19, 327-348.

PARDO, C., CuBAS, P., TAHIRI, H., 2004: Molecular phylogeny and systematics of Genista (Leguminosae) and related genera based on nucleotide sequences of nrDNA (ITS region) and cpDNA (trnL-trnF intergenic spacer). Plant Systematics and Evolution 244, 93-119.

PERCY, D. M., CRONK, Q. C. B., 2002: Different fates of island brooms: contrasting evolution in Adenocarpus, Genista and Teline (Genisteae, Fabaceae) in the Canary Islands and Madeira. American Journal of Botany 89, 854-864.

PIGNATTI, S., 1982: Flora d'Italia 1, 636-644. Edagricole, Bologna.

RizZi LONGO, L., FEOLi CHIAPELLA, L., 1993: Palynotaxonomy of Genista sericea group. Proceedings 5th OPTIMA Meeting, Istanbul, 745-760.

RizZI LONGO, L., FeOLI CHIAPELLA, L., 2009: Pollen morphology and taxonomy of Genista sect. Spartioides (Genisteae-Fabaceae). Flora Mediterranea 19, 141-160.

SudA, J., KYNCL, T., JAROLIMOVA, V., 2005: Genome size variation in Macaronesian angiosperms: forty percent of the Canarian endemic flora completed. Plant Systematics and Evolution 252, 215-238. 
TAMURA, K., 1992: Estimation of the number of nucleotide substitutions when there are strong transition-transversion and $\mathrm{G}+\mathrm{C}$-content biases. Molecular Biology and Evolution 9, 678-687.

Tamura, K., Peterson, D., Peterson, N., Stecher, G., Nei, M., Kumar, S., 2011: MEGA5: Molecular evolutionary genetics analysis using maximum likelihood, evolutionary distance, and maximum parsimony methods. Molecular Biology and Evolution 28, 2731-2739.

VižInTIN, L., JAVORNIK, B., BOHANEC, B., 2006: Genetic characterization of selected Trifolium species as revealed by nuclear DNA content and ITS rDNA region analysis. Plant Science 170, 859-866.

White, T. J., Bruns, T., LEe, S., TAYlor, J., 1990: Amplification and direct sequencing of fungal ribosomal RNA genes for phylogenetics. In: InNIS, M. A., GELFAND, D. H., SNinsky, J. J., White, T. J. (eds.), PCR protocols: A guide to methods and applications, 315-322. Academic press, San Diego. 